\title{
Morphological Alterations in the Peripheral and Central Nervous Systems of Mice Lacking Glial Cell Line-Derived Neurotrophic Factor (GDNF): Immunohistochemical Studies
}

\author{
Ann-Charlotte E. Granholm, ${ }^{1,2,3}$ Nisha Srivastava, ${ }^{1}$ Justin L. Mott, ${ }^{1}$ Stephanie Henry, ${ }^{1}$ Michael Henry, ${ }^{1}$ \\ Heiner Westphal, ${ }^{4}$ Jose G. Pichel, ${ }^{4}$ Liya Shen, ${ }^{4}$ and Barry J. Hoffer ${ }^{2,3}$ \\ Departments of ${ }^{1}$ Basic Science and ${ }^{2}$ Pharmacology and ${ }^{3}$ Neuroscience Training Program, University of Colorado Health \\ Sciences Center, Denver, Colorado 80262, and ${ }^{4}$ National Institute of Child Health and Human Development, LMGD, \\ National Institutes of Health, Bethesda, Maryland 20892
}

Glial cell line-derived neurotrophic factor (GDNF) is a member of the TGF- $\beta$ superfamily of growth factors with neurotrophic activity on midbrain dopaminergic neurons and on developing and mature motoneurons of the brainstem and spinal cord. To investigate the extent of GDNF dependency of central and peripheral nervous structures during development, we have performed an immunohistochemical analysis of sections from the whole head including brain, peripheral ganglia, developing teeth and tongue, as well as intestines, in mutant mice lacking a part of the third exon that encodes the GDNF protein. As described previously, these null-mutated mice lack most of the enteric nerve plexus and are subject to agenesis or severe dysgenesis of the kidneys. In the present communication, we examined the development of vibrissae and incisor and molar teeth, as well as the innervation of these structures, and found no differences between null-mutated and control mice. A decrease in the immunohistochemical labeling intensity with tyrosine hydroxylase was observed in the superior cervical ganglion (SCG), as well as in the pontine nucleus locus coeruleus, and the sympathetic innervation of blood vessels and glands in the head was significantly decreased. None of the brain nuclei studied exhibited any significant decreases in the total number of neurons, but the packing density of neurons in the nucleus locus coeruleus was decreased. These data indicate that GDNF might be one neurotrophic factor that contributes to the development of central and peripheral noradrenergic neurons.

Key words: glial cell line-derived neurotrophic factor; aminergic neurons; substantia nigra; locus coeruleus; gastrointestinal innervation; tooth development; basal forebrain
Glial cell line-derived neurotrophic factor (GDNF) was recently purified from a rat glial cell line (B49) (Lin et al., 1993) and found to have profound effects on the survival, high-affinity dopamine uptake, and neurite outgrowth of cultured midbrain dopaminergic neurons (Lin et al., 1993; Choi-Lundberg and Bohn, 1995). We and others have also demonstrated that midbrain dopaminergic neurons are affected by this trophic molecule in the intact adult animal (Hudson et al., 1995) and after lesions (Hoffer et al., 1994; Bowenkamp et al., 1995; Kearns and Gash, 1995; Lindner et al., 1995; Sauer et al., 1995; Tomac et al., 1995; Gash et al., 1996). Because mRNA for GDNF has been found in many nondopaminergic areas in the developing rat brain (Schaar et al., 1993; Springer et al., 1994; Arenas et al., 1995; Choi-Lundberg and Bohn, 1995; Trupp et al., 1995), this neurotrophic factor may have actions on other neuronal populations as well.

Recently, it has been demonstrated that GDNF is also a potent neurotrophic factor for motoneurons (Zurn et al., 1994; Li et al., 1995). A positive effect of GDNF on forebrain cholinergic neurons has also been shown using the fimbria-fornix lesion model in rats (Williams et al., 1996). Cerebellar Purkinje neurons have been found to be affected by GDNF (Mount et al., 1995), and the

Received Aug. 29, 1996; revised Nov. 18, 1996; accepted Nov. 22, 1996.

This work was supported by National Institutes of Health Grants MH49661, NSO9199, AG04418, and AG12122.

Correspondence should be addressed to Dr. Ann-Charlotte Granholm, Department of Basic Science, P.O. Box C286, University of Colorado Health Sciences Center, 4200 East 9th Avenue, Denver, CO 80262.

Copyright (C) 1997 Society for Neuroscience $\quad 0270-6474 / 97 / 171168-11 \$ 05.00 / 0$ development of spinal cord tissue is promoted by GDNF in fetal intraocular transplants (Trok et al., 1996). Thus, GDNF has pronounced effects on both developing and mature neurons of several different phenotypic origins. Therefore, a broader evaluation of the dependency of CNS neurons on GDNF during development would be of great interest.

To examine the physiological role of neurotrophic factors in the developing mammalian brain, genetically modified null-mutated ("knock-out") animals that lack such factors can be generated. We and others have recently presented data from null-mutated mice lacking expression of GDNF (Moore et al., 1996; Pichel et al., 1996; Sanchez et al., 1996). The following alterations in these animals have been reported: agenesis or severe dysgenesis of the kidneys, absence of the enteric nervous system, a reduction in the number of some motor neurons (Moore et al., 1996), and a significant reduction in the number of neurons in the nodose ganglion and the SCG (Moore et al., 1996).

However, GDNF expression is also seen in developing teeth, taste buds, vibrissae, and trigeminal nuclei (Schaar et al., 1993; Choi-Lundberg and Bohn, 1995; Trupp et al., 1995), and the chick SCG is sensitive to GDNF administration in vitro (Buj-Bello et al., 1995; Ebendal et al., 1995). Therefore, potential alterations of these structures were also evaluated. The following specific questions were addressed in the present study. (1) Are there alterations in transmitter synthetic enzymes in dopaminergic, noradrenergic, or cholinergic neurons in the brain? (2) Are there alterations in tyrosine hydroxylase staining in SCG? (3) Does a 

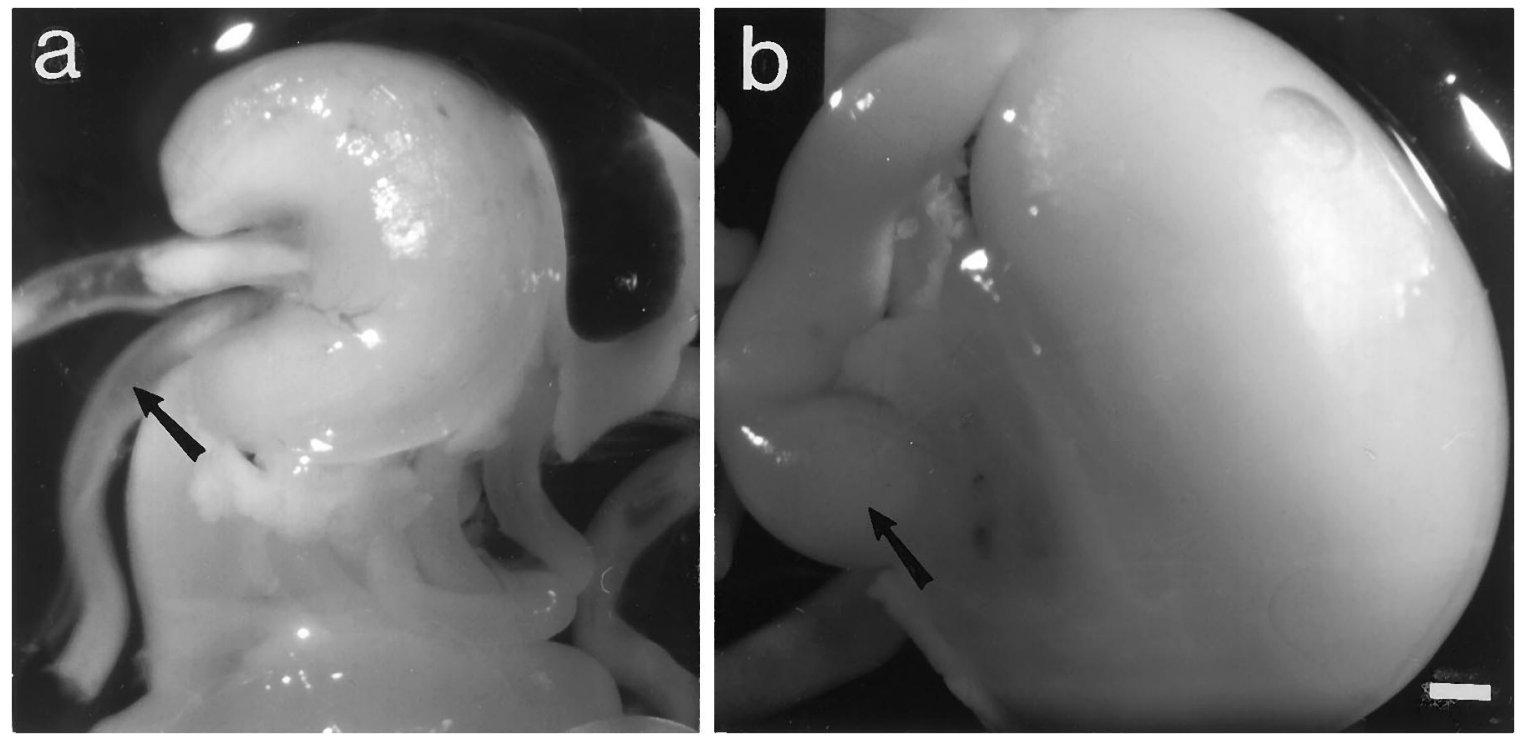

Figure 1. Microphotograph of stomach from a GDNF $-/-\operatorname{animal}(a)$ and a $+/+$ animal $(b)$. Note the difference in the appearance of the stomach. The ventricle of the $+/+$ animal is filled with milk and distended, whereas the ventricle in the $-/-$ animal appears to be empty and much smaller in size. Note the difference in thickness of the duodenal wall (arrow) between the $-/-$ and $+/+$ animal. Scale bar (shown in $b$ ), $1 \mathrm{~mm}$.

null mutation of the GDNF gene result in disturbances in tooth germ or taste bud development?

\section{MATERIALS AND METHODS}

Production of null mutations in the murine GDNF locus. A nonfunctional allele of the GDNF gene was generated by replacing part of the third exon that encodes GDNF protein (Lin et al., 1993) with a cassette expressing the selectable marker neomycin phosphotransferase. The targeting construct was linearized and transfected into J1 or R1 embryonic stem cells, and chimeric mice were produced either by blastocyst injection or by morula aggregation. $\mathrm{CD} 1$ or $\mathrm{C} 57 \mathrm{BL} / 6$ recipient strains were used to obtain germline transmission of the targeted allele. Six clones were identified with the predicted mutant allele. Four clones produced chimeric mice that transmitted the mutation to their progeny. Heterozygous offspring were viable and fertile, whereas mice homozygous for the mutant allele (GDNF-/-) died 12-24 hr postpartum. The production of null-mutated mouse strains used here has been described in detail elsewhere (Pichel et al., 1996).

Table 1. Vibrissae number and length in $-/-,+/-$, and $+/+$ animals

\begin{tabular}{lll} 
& $\begin{array}{l}\text { Vibrissae } \\
\text { number }\end{array}$ & $\begin{array}{l}\text { Vibrissae } \\
\text { length (in cm) }\end{array}$ \\
\hline Wild type & 48 & 1.27 \\
Heterozygous & 38 & 0.98 \\
Knock-out & 45 & 1.03 \\
Knock-out & 45 & 1.24 \\
\hline
\end{tabular}

Table 2. Measurements of developing molars and incisors.

\begin{tabular}{lccc} 
& Knock-out & & Wild type \\
\hline Molar width & $795 \pm 191$ & $p<0.9$ & $770 \pm 183$ \\
Molar length & $625 \pm 136$ & $p<0.4$ & $490 \pm 27$ \\
Incisor width & $637 \pm 35$ & $p<0.9$ & $633 \pm 55$ \\
Incisor length & $937 \pm 131$ & $p<0.9$ & $921 \pm 27$ \\
Enamel thickness & $91 \pm 0.4$ & $p<0.1$ & $82 \pm 3.4$ \\
Pulp width & $457 \pm 34$ & $p<0.9$ & $447 \pm 50$ \\
\hline
\end{tabular}

The data are expressed in micrometers; $n=3$ per group.
Immunohistochemistry. Whole heads or dissected brains and bisected abdominal tissues were fixed by immersion in $4 \%$ paraformaldehyde overnight and transferred to $30 \%$ sucrose in PBS (0.1 M, pH 7.4). Coronal and sagittal sections of the tissues were collected on gelatin-coated slides and washed in PBS. Every 10th section was collected for routine histological evaluation using hematoxylin-eosin staining after dehydration. The sections used for immunohistochemistry were incubated overnight with antibodies directed against neurofilament (NF, 1:100; Dako, Carpenteria, CA), choline acetyltransferase (ChAT, 1:10; BoehringerMannheim, Indianapolis, IN), tyrosine hydroxylase (TH, 1:200; Eugene Tech, Ridgefield Park, NJ), PGP 9.5 (1:200; Accurate Chemicals and Scientific, Westbury, NY), or dopamine $\beta$ hydroxylase (DBH, 1:200; Eugene Tech) in a humid chamber at $4^{\circ} \mathrm{C}$. They were rinsed three times for 10 min each in PBS and were then incubated for $1 \mathrm{hr}$ in room temperature with IgG directed against the appropriate species, conjugated with fluorescein isothiocyanate (FITC, 1:30, Dako) or rhodamine (1:50, Dako). The sections were rinsed again three times for $10 \mathrm{~min}$ each in PBS and were coverslipped with glycerol/PBS (9:1). They were studied in a Nikon Optiphot epi-illumination microscope. Sections in which the primary or secondary antibody was omitted were included as controls. Because the indirect immunofluorescence technique does not allow for direct confirmation of antigen location, description in the text of "immunoreactive" or "positive" always means "like immunoreactivity." For details on immunohistochemical techniques, see Granholm et al. (1994).

Image analysis. The packing density of TH and ChAT immunoreactive neurons, as well as the average staining density and cell size, was calculated in brainstem and forebrain sections using National Institutes of Health Image software system and a Cohu video camera (4990 series, Colorado Video, Boulder, CO) coupled to a Quadra 450 computer (Apple Computer, Cupertino, CA) (Bowenkamp et al., 1995). An image of the section was captured with the $10 \times$ objective, and the cells were counted on unaltered images. The cells in every 10th section were evaluated from both groups. The mean diameter of these cells was also calculated (for additional details, see Bowenkamp et al., 1995). To determine the packing density of cells in the locus coeruleus (LC),

Table 3. Measurements of staining ratio, cell size, and cell packing density in LC of wild-type and knock-out animals

\begin{tabular}{lccc} 
& Knock-out & & Wild type \\
\hline Cell size $\left(\mu \mathrm{m}^{2}\right)$ & $103 \pm 5 \%$ & $p<0.96$ & $100 \pm 5 \%$ \\
Cells per $100,00 \mu \mathrm{m}^{2}$ & $47 \pm 5$ & $p<0.04$ & $70 \pm 8$ \\
Staining ratio & $1.22 \pm 0.05$ & $p<0.05$ & $1.49 \pm 0.06$ \\
\hline
\end{tabular}




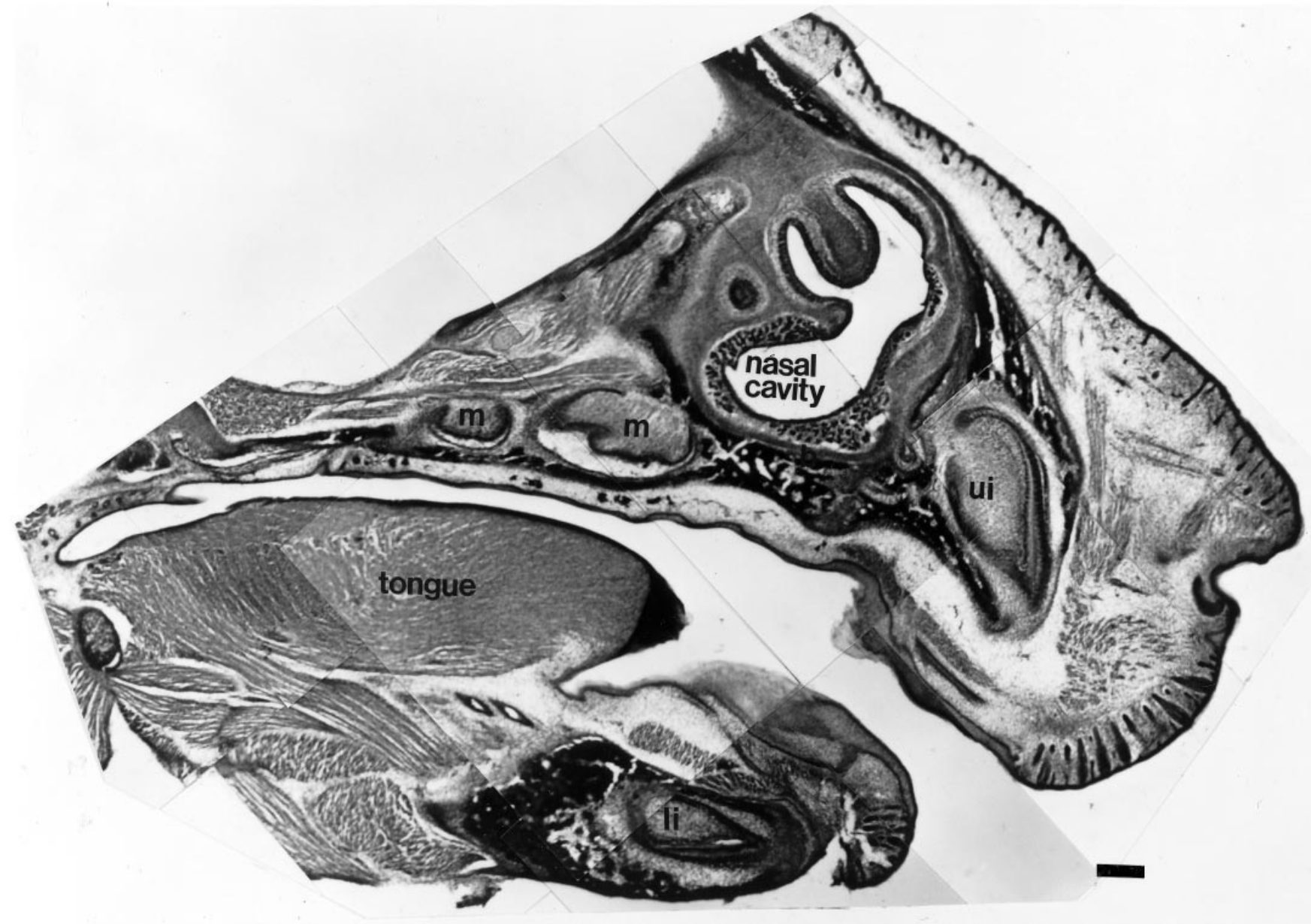

Figure 2. Hematoxylin-eosin staining of section of a whole head in a knock-out animal. There are no observable differences in the development of the craniofacial components. $u i$, Upper incisor; $l i$, lower incisor; $m$, molar. Scale bar (bottom right corner), $250 \mu \mathrm{m}$.

substantia nigra, and septal forebrain, the number of neurons within $100,000 \mu \mathrm{m}^{2}$ was counted on five sections from each nucleus in five knock-out and four control brains. The values were then averaged within each brain and by group. Only structures with a nucleus and two or more processes were counted as neurons. All data collected in quantitative analyses were statistically evaluated using Student's $t$ test for comparison of means. In addition to the cell counts, optical staining densities were obtained from sections incubated with $\mathrm{TH}$ or ChAT antibodies. Unaltered images were acquired with the $10 \times$ objective, and background was subtracted using nonstained portions of the section. Thereafter, the entire area of the nucleus was traced, and optical densities were obtained from five sections in each nucleus. The values are presented as background-to-staining ratios. The same image analysis system was used to determine the length and thickness of incisors and molars as well as enamel and pulp width in developing teeth of GDNF $+/+$ and $-/-$ animals. The range of values was set by a scale bar in the eye piece of the microscope.

\section{RESULTS}

\section{Gastrointestinal system}

As has been reported previously by us and others (Moore et al., 1996; Pichel et al., 1996; Sanchez et al., 1996), the GDNF-/animals exhibited a severe disturbance in the development of the gastrointestinal tract. Figure 1 depicts the gross appearance of the stomach in a newborn GDNF $-/-$ animal (Fig. $1 a$ ) versus the stomach in a newborn wild-type (GDNF $+/+$ ) animal (Fig. 1b). As can be seen in this figure, the stomachs in the wild-type animals were distended and contained much milk, whereas the stomachs in the newborn GDNF-/- animals were much smaller and appeared to contain only small amounts of milk. It was also evident from inspection that the small and large intestines in the wild-type animals (Fig. 1b) were fully developed and had reached a more mature appearance with thick walls and larger outer diameters than the intestines in the GDNF-/- animals (Fig. 1a). In addition to these differences in gross appearance, the small and large intestines of the GDNF+/+ animals showed signs of debris in the lumen, suggesting that digestion was taking place, whereas the GDNF-/- animals showed no signs of debris or digestion.

\section{Whole-body and cranio-facial development}

There were no differences in body size and limb length between the GDNF $+/+$ and $-/-$ animals. The mean crown-to-rump length in the $+/+$ group was $2 \mathrm{~cm}$, and the mean length in the $-/-$ group was $2.2 \mathrm{~cm}$. Furthermore, the vibrissae were counted on the animals and exhibited no differences among the wild-type, heterozygous, or GDNF-/- animals in number or size (Table 1).

The development of the jaws and teeth was investigated next. Figure 2 depicts a photo montage of a head from a knock-out mouse, stained with hematoxylin-eosin. No gross differences between the two groups were observed in general development of the head, including the nasal and oral cavities. The size of developing lower and upper incisors and molars, as well as the 

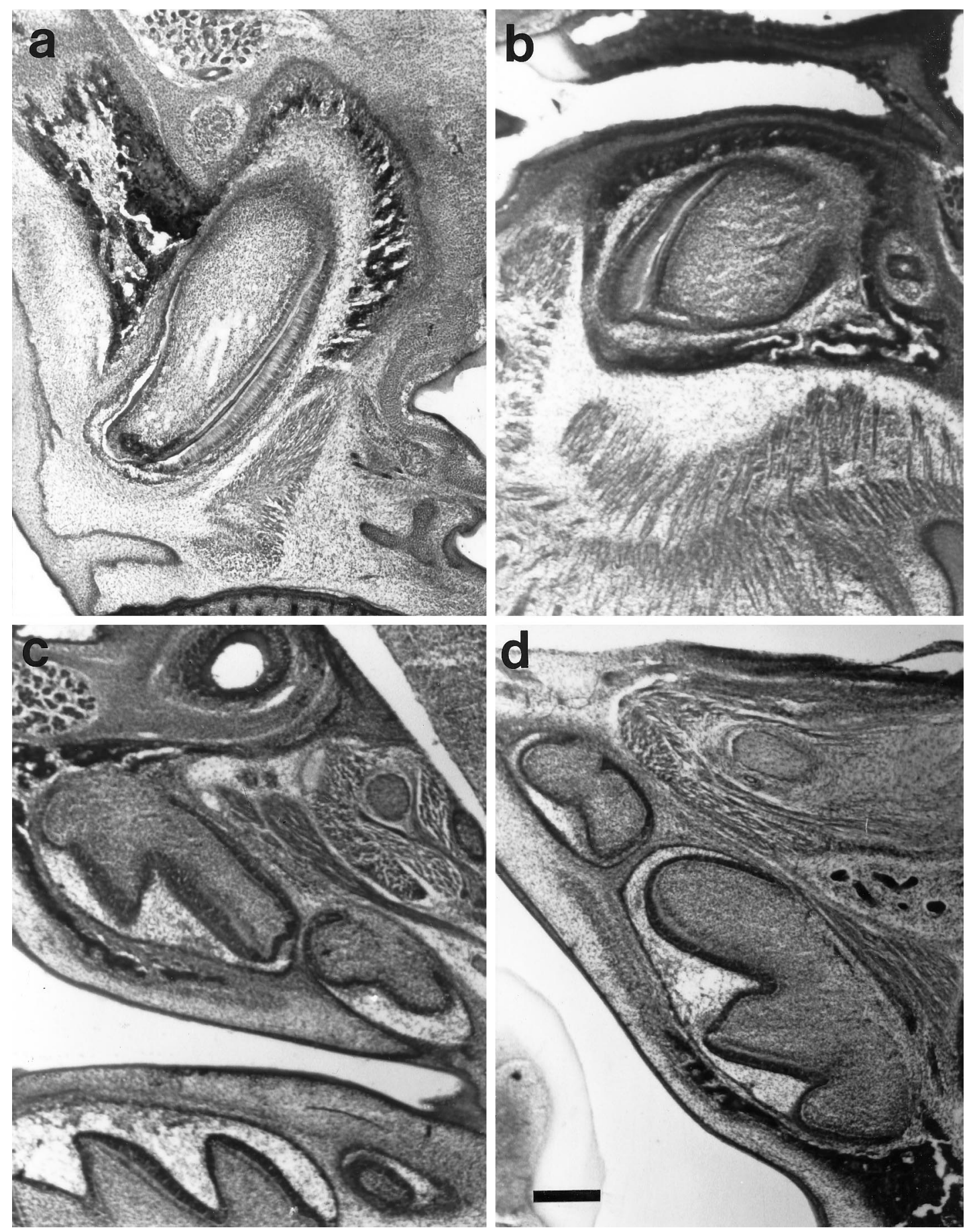

Figure 3. Incisors $(a, b)$ and molars $(c, d)$ in a knock-out animal $(a, c)$ and a wild-type animal $(b, d)$ stained with hematoxylin-eosin. There are no observable differences in molar or incisor development, enamel thickness or length, or width of the teeth. Scale bar (shown in $d$ ), $180 \mu \mathrm{m}$.

thickness of newly formed enamel and the width of the tooth pulp versus the enamel/dentin thickness, was measured using a computerized image analysis system (see Materials and Methods). Both molars and incisors were found to be identical in size in the two groups during development, at least until postnatal day 0 (Table 2 and Fig. 3). Immunohistochemical analyses with antibodies directed against PGP 9.5 (which stains the neurites and cell bodies of neurons) and NF was used to determine the extent of innervation of the oral and nasal cavities and the facial skin. No differences in sensory or motor innervation densities of the oral cavity taste buds or tongue, skin surrounding the vibrissae, or the olfactory epithelium in the nasal cavity could be seen (Fig. $4 a, b$ ). In contrast to the sensory and motor innervation of the face and oral and nasal cavities, we found significant differences in the sympathetic innervation of the face. There was a significant decrease in $\mathrm{TH}$ immunohistochemical staining in the SCG of the GDNF - /group compared with the $+/+$ group (Fig. $4 c, d$ ). The density of sympathetic nerve fibers was also decreased in GDNF-/animals, both in the glands of the nasal cavity lamina propria 

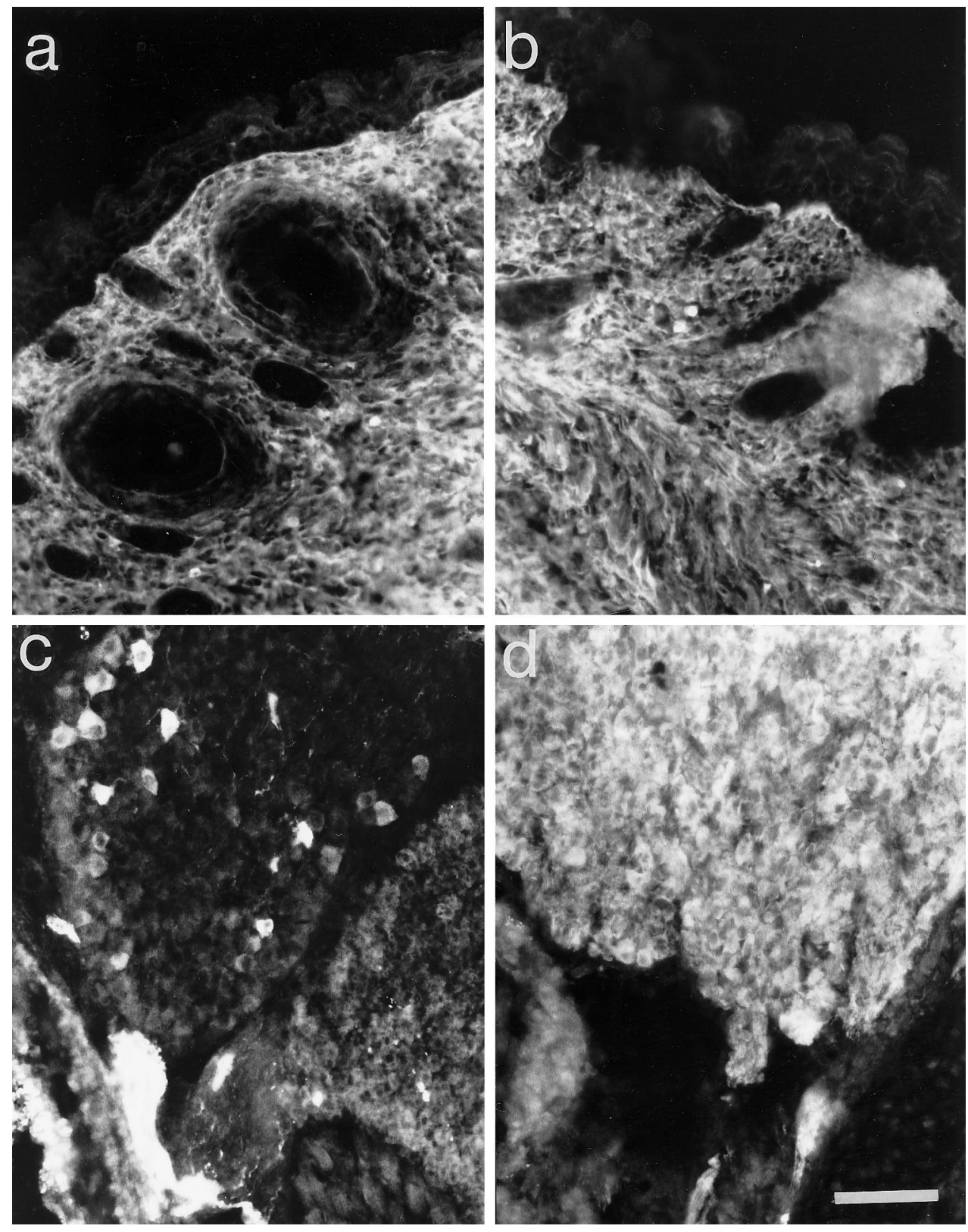

Figure 4. NF immunohistochemistry showing innervation of the skin of the nose, including vibrissae, from a knock-out animal (a) and a wild-type animal $(b)$. There are no differences in innervation densities between the two animals. Sections of SCG stained with TH antibodies in a knock-out animal (c) and a wild-type animal $(d)$. The TH staining is significantly decreased in the knock-out compared with the wild-type animal. Scale bar (shown in $d$ ), $100 \mu \mathrm{m}$.

(Fig. 5a,b) and in blood vessels in the facial structures (Fig. $5 c, d)$, compared with GDNF $+/+$ animals.

\section{Immunohistochemistry of the brain}

Because GDNF has been described as a neurotrophic factor for midbrain dopaminergic and pontine noradrenergic neurons, these two neuronal phenotypes were investigated with immunohistochemical and image analysis techniques. There were no statistical differences between knock-out and wild-type mice in cell packing density, TH staining density, or cell size in the substantia nigra (Fig. 6). The mean cell packing density in the GDNF $-/-$ group was $78 \pm 1$ cells $/ 100,000 \mu \mathrm{m}^{2}(n=3)$, and in the $+/+$ group it was $63 \pm 5(n=4)$ cells per $100,000 \mu \mathrm{m}^{2}$. The mean background/ staining ratio in the substantia nigra of GDNF $-/-$ mice was
$1.5 \pm 0.2$ and in the $+/+$ group $1.4 \pm 0.05$. The average cell body size of TH-immunoreactive neurons in the substantia nigra was also similar between the two groups. The mean cell size in the GDNF $-/$ - group was $120 \pm 16 \%$ of controls $(n=3)$.

In contrast to the results in the substantia nigra, there were significant alterations in these values between knock-out and wild-type mice in the pontine nucleus LC (Table 3). The mean cell size was not different between the groups. Likewise, the area occupied by cell bodies was not altered in the LC of GDNF -/compared with wild-type controls. However, the cell packing density within this area was significantly lower in the knock-out group compared with controls. In addition, the background/staining ratio for $\mathrm{TH}$ immunohistochemical staining was also signifi- 

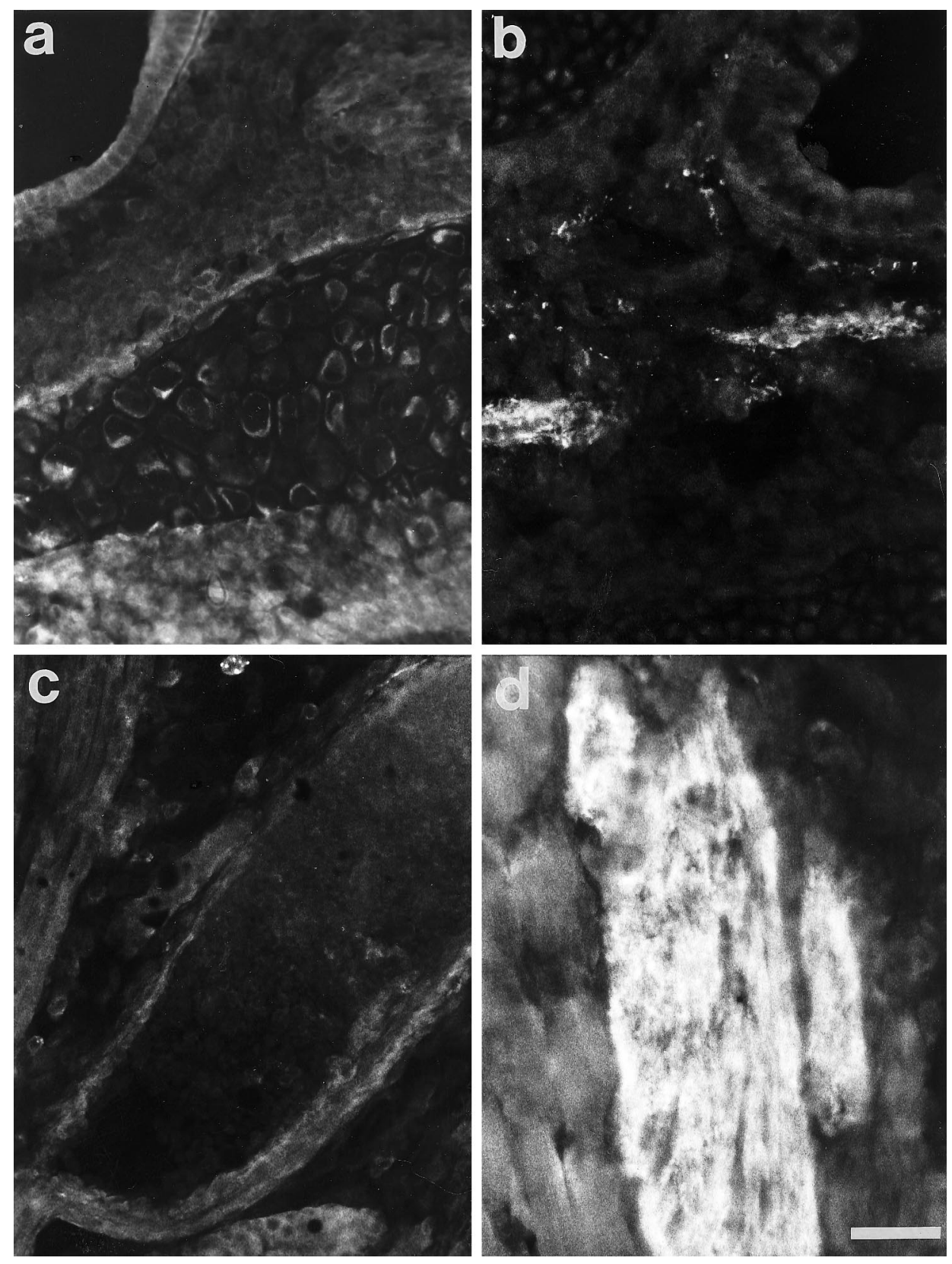

Figure 5. TH immunohistochemistry in sections from the nasal mucosa $(a, b)$ and the wall of major facial blood vessels $(c, d)$. The microphotographs in $a$ and $c$ are from $-1-$ animals, and $b$ and $d$ are from $+/+$ animals. Note the decrease in innervation, both in the blood vessel and in the respiratory mucosal lining, in the $-/-$ animals, compared with controls. Scale bar (shown in $d$ ), $125 \mu \mathrm{m}$.

cantly lower in the GDNF - /- group compared with the +/+ group (Table 3). Double staining of the LC nucleus with DBH and $\mathrm{TH}$ antibodies was performed in both groups. Figure 7 illustrates $\mathrm{TH}(a, c)$ and DBH $(b, d)$ staining in the LC of animals in both groups. As can be seen, LC neurons in the knock-out mice exhibited a significant reduction in staining and cell packing density (cells/100,000 $\mu \mathrm{m}^{2}$ Table 3 ), even though individual neurons were not smaller in size. It did not appear as if the decreased TH immunoreactivity observed in the LC of GDNF - / - animals was attributable to an accelerated cell loss in this nucleus, because cresyl violet-stained sections appeared to contain the same packing density of large neurons in the LC in both groups examined (Fig. 7e,f). Thus, it is likely that a decrease in synthesis of the $\mathrm{TH}$ enzyme has occurred in individual neurons in the GDNF -/animals. The $\mathrm{TH}$-immunoreactive staining distribution was also examined in major pathways, such as the medial forebrain bundle and the fimbria-fornix (Fig. $8 a$ ). No differences could be observed between the GDNF -/- (Fig. 8a) and the wild-type controls in any of these pathways. TH-immunoreactive neurons in the ventral tegmental area were also investigated in the two groups, and no noticeable differences were seen in either cell size or staining intensity (Fig. 8b). In addition, the cholinergic neurons in the medial forebrain region were examined. There appeared to be no differences in cell size, ChAT staining intensity, or cell number in this cell group between the GDNF $-/-$ and the $+/+$ animals (Fig. $8 d$ ). The ChAT immunoreactivity of other forebrain structures, such as the olfactory bulb (Fig. $8 c$ ), was also investigated, and again no observable differences in the ChAT-immunoreactive structures could be observed.

\section{DISCUSSION}

Since the discovery of GDNF a few years ago (Lin et al., 1993), most effects of this trophic factor have been described for the midbrain dopaminergic neurons. GDNF increases high-affinity 


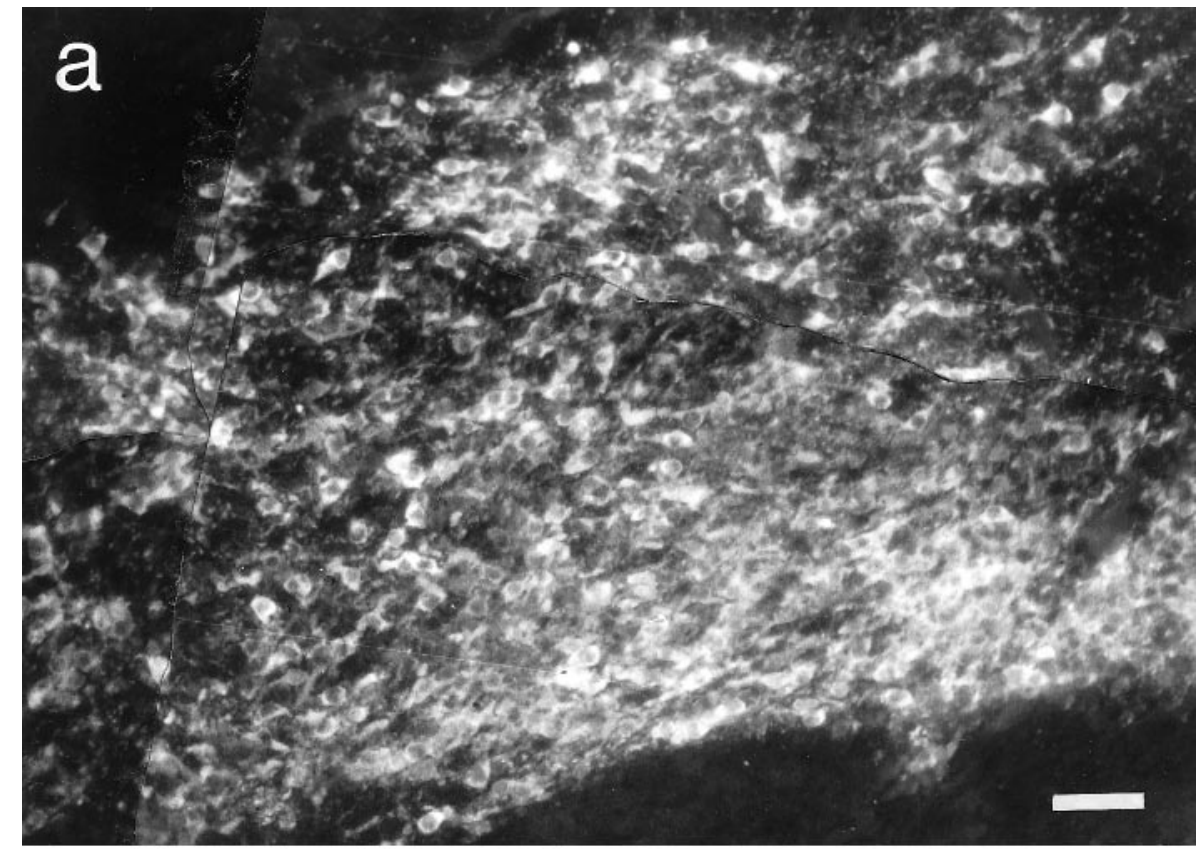

Figure 6. Substantia nigra sections incubated with $\mathrm{TH}$ antibodies. $a$, A section from a knockout animal, and $b$, from a wild-type animal. As can be seen from this figure, there were no observable differences between the two groups in packing density or staining ratio. Scale bar (shown in $a$ ), $90 \mu \mathrm{m}$.

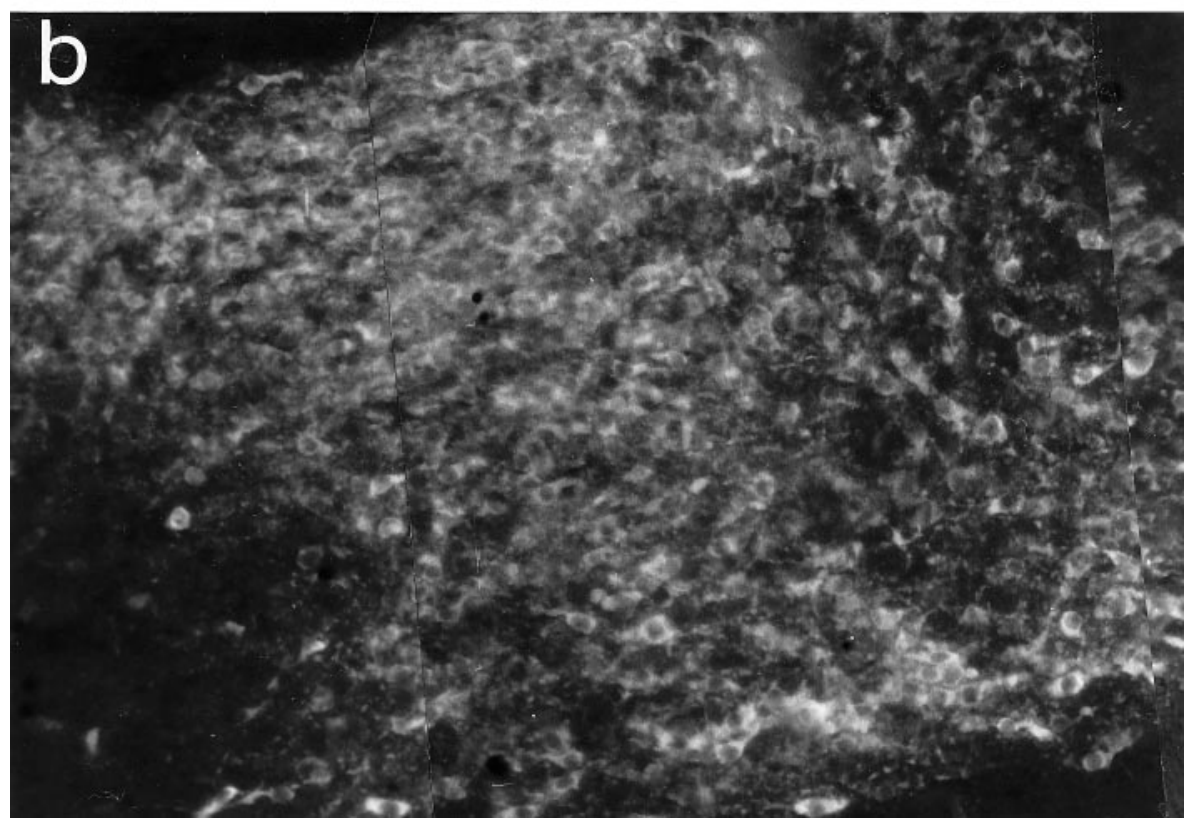

dopamine uptake and number of tyrosine hydroxylaseimmunoreactive neurons in mesencephalic cultures (Lin et al., 1993). This trophic factor also prevents nigral dopaminergic degeneration after striatal (Sauer et al., 1995) or medial forebrain bundle 6-OHDA injection in the rat (Bowenkamp et al., 1995; Kearns and Gash, 1995), after surgical axotomy of the nigrostriatal pathway (Beck et al., 1995), and after MPTP administration in mice and nonhuman primates (Tomac et al., 1995; Gash et al., 1996). Recently, a more widespread spectrum of GDNF sensitivities in both the PNS and CNS has been reported. Several different studies have shown marked effects of GDNF treatment, on both developing and adult spinal cord motoneurons (Henderson et al., 1994; Li et al., 1995; Oppenheim et al., 1995; Trok et al., 1996). It has also been shown that Schwann cells and skeletal muscle contain GDNF mRNA and that the GDNF message is upregulated after axotomy of adult spinal nerves (Springer et al., 1995). Brainstem noradrenergic neurons of the LC have also been found to be sensitive to GDNF administration. Transplants of fibroblasts engineered to produce high levels of GDNF prevented LC neuronal loss after 6-OHDA and induced fiber sprouting and enhancement of noradrenergic phenotype in the intact rat (Arenas et al., 1995). To our knowledge, there are no other neurotrophic factors that are known to effectively support the survival of central noradrenergic neurons, even though some effects of neurotrophin-3 have been reported on these neurons, both in vivo (Arenas et al., 1994) and in vitro (Friedman et al., 1993).

Central cholinergic neurons, primarily the motoneurons of the midbrain cranial nerve nuclei, have also been shown to be affected by GDNF treatment. GDNF was found to increase the activity of ChAT in cultures from rat mesencephalon, and facial nerve axotomy resulted in a 50\% decrease in motoneuron degeneration if GDNF was applied (Zurn et al., 1994; Yan et al., 1995). These earlier results encouraged us to carry out a more generalized investigation of the effects of lack of GDNF 

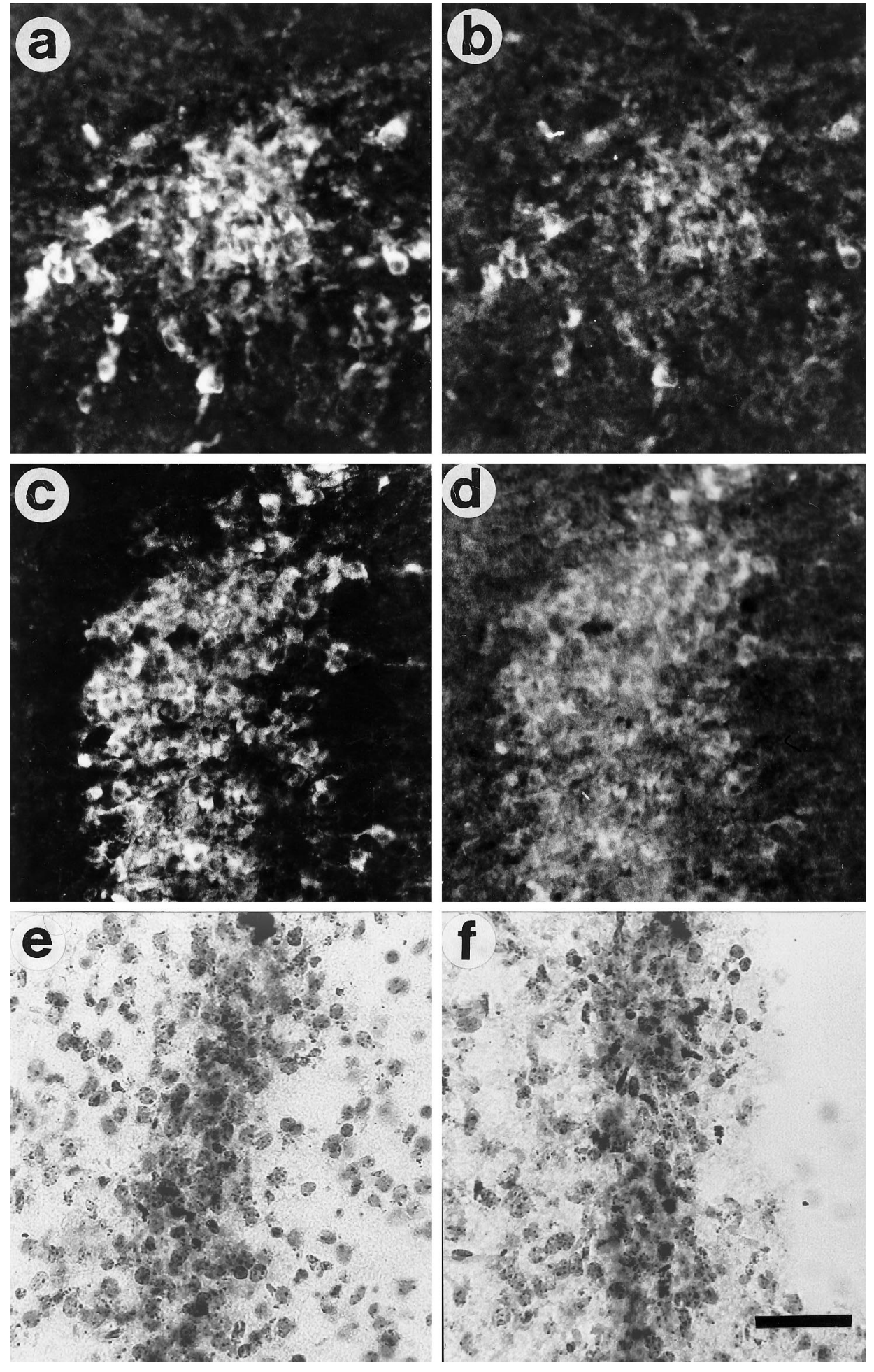

Figure 7. Immunohistochemistry with double labeling on the same section using $\mathrm{TH}(a$, $c)$ and DBH $(b, d)$ antibodies in the pontine nucleus LC. The packing density of cells was decreased in the knock-out animals $(a, b)$ compared with the wild-type controls $(c, d)$. The TH staining intensity was also decreased in the GDNF $-/-$ animals $(a)$ versus controls $(c)$. Cresyl violet-stained sections from the LC of a GDNF $-/-$ animal $(e)$ and a wildtype animal $(f)$ are also shown. Note that there is no evident difference in the number of neurons in this nucleus with the routine staining. Scale bar (shown in $f$ ), $100 \mu \mathrm{m}$. during early development in both PNS and CNS. As was also described by Moore et al. (1996), we found a decrease in the number of TH-immunoreactive neurons in the SCG of GDNF-/- mice and also severe deficiencies in the enteric nervous system. However, here we describe novel findings of a significant decrease in $\mathrm{TH}$ immunoreactivity in central noradrenergic LC neurons and a decrease in the packing density of these neurons. Here, we also report a detailed investigation of the tooth and taste bud development, in which we found no disturbances in the GDNF knock-out mice, compared with wild-type controls.

The results obtained from knock-out gene manipulation experiments do not rule out the possibility that GDNF is important for the development of various brainstem nuclei, because the brain may be able to compensate for loss of any one factor during development. This compensatory function of CNS neurons has been shown in at least some of the knock-out mice that lack other neurotrophic factors, such as nerve growth factor (NGF) (Crowley 

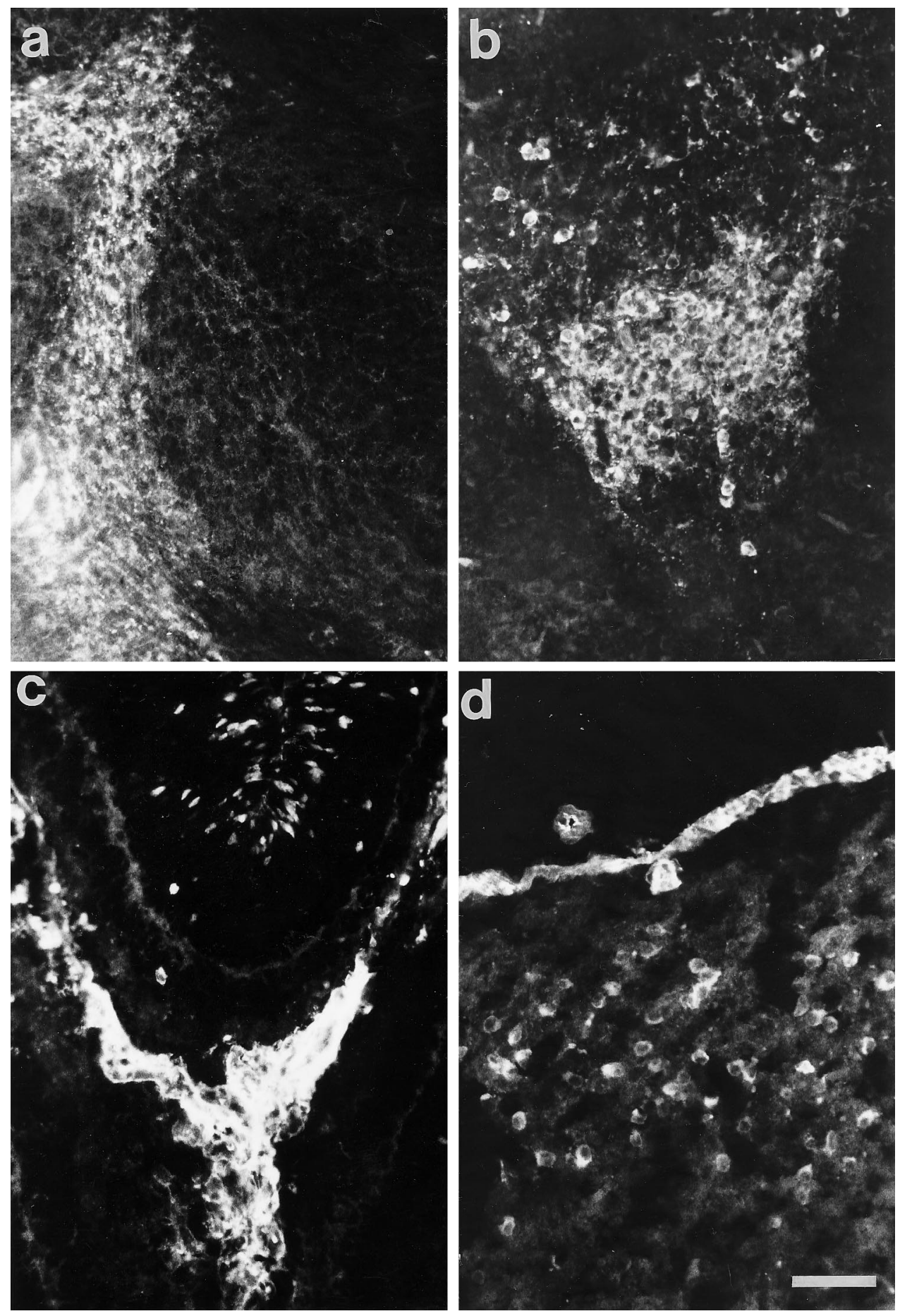

Figure $8 . \quad$ The TH immunoreactivity in the fimbria-fornix $(a)$ and the ventral tegmental area $(b)$ in a GDNF knock-out animal. There were no observable differences in staining density or distribution between the two groups in either of these regions with this antibody. $c, d$, Immunoreactivity with ChAT antibodies in a knock-out animal in the olfactory bulb (c) and the basal forebrain $(d)$. Also in these regions, the distribution of transmitter-specific elements was similar between the wild-type and knock-out animals. Scale bar (shown in d), $100 \mu \mathrm{m}$.

et al., 1994), brain-derived neurotrophic factor (Ernfors et al., 1990), and neurotrophin-3 (Ernfors et al., 1994; Farinas et al., 1994). For example, it has been demonstrated that early development of the forebrain cholinergic neurons is not compromised in animals that are lacking NGF (Crowley et al., 1994), despite the fact that these cholinergic neurons have been shown to be dependent on NGF for normal development (Honegger and Lenoir, 1982; Gnahn et al., 1983). However, there was a decrease of ChAT staining in NGF knock-out mice, similar to that found for $\mathrm{TH}$ staining in the nucleus LC of GDNF knock-out mice in the present study. Therefore, it would be interesting in future experiments to determine whether there are any alterations in the continued development of dopaminergic and noradrenergic central neurons in the GDNF knock-out mice, perhaps by using syngeneic or allogeneic transplantation of embryonic tissue into intact hosts (Strömberg et al., 1993).

The cholinergic neurons of the septal forebrain did not appear to be affected in the GDNF -/- mice. This finding correlates well with previous studies that failed to detect any effects of GDNF administration during development of the cholinergic forebrain neurons, both in vitro (Zurn et al., 1994) and in intraocular transplants (Price et al., 1997), even though a recent study has shown positive effects of GDNF on fimbria-fornix transected forebrain cholinergic neurons (Williams et al., 1996). In our in 
oculo transplant study, we found a significant enhancement of forebrain GABAergic neuron numbers after GDNF administration (Price et al., 1997). Again, it would be interesting in future studies to determine whether GABAergic neuron development is disturbed in GDNF - /- mice compared with controls.

Earlier studies have also shown that GDNF promotes the survival of chick embryonic sympathetic and nodose neurons in culture (Buj-Bello et al., 1995; Ebendal et al., 1995), and it was also recently demonstrated by Moore et al. (1996) that the GDNF knock-out mice have a significant reduction in the number of these ganglion neurons ( $40 \%$ for nodose, $35 \%$ for SCG). These data are in line with our findings that the immunohistochemical labeling of tyrosine hydroxylase is reduced in the SCG cells in the GDNF $-/-$ mice and also that the sympathetic innervation is decreased in blood vessels and glands of the oral and nasal mucosa. Contrary to this decreased sympathetic innervation, preliminary studies of the distribution of $\mathrm{TH}$-immunoreactive neurites in cortical areas and pathways did not reveal any observable differences between the knock-out and wild-type animals (Fig. 8). However, it is likely that these TH-positive profiles originate from both nigral dopaminergic and brainstem noradrenergic neurons, so it is difficult to discern whether there were any vast changes in noradrenergic innervation, in addition to the staining changes seen in the cell bodies themselves. Additional studies using antibodies against $\mathrm{DBH}$ and dopamine could reveal whether there were distinguishable differences. It is interesting to note that peripheral neurons appear to be more sensitive to gene manipulation of the neurotrophic factors than the central neurons. This is true for both NGF knock-out animals, in which the sensory and sympathetic ganglia fail to develop (Crowley et al., 1994) and for the GDNF knock-out animals studied here. However, because recent studies have shown that GDNF mRNA expression is significantly higher in peripheral organs than in the CNS (Trupp et al., 1995), our findings in the present study are not surprising.

Despite the potential clinical importance of GDNF for neurodegenerative disease, its mechanism of action is largely unknown. Recently, it has been demonstrated that physiological responses to GDNF require the presence of a novel glycosyl-phosphatidyl inositol-linked protein that has been termed GDNFR- $\alpha$ (Jing et al., 1996; Treanor et al., 1996). This receptor is expressed on GDNF-responsive cells and binds GDNF with high affinity (Jing et al., 1996; Treanor et al., 1996). It was further demonstrated that GDNF promotes the formation of a physical complex between GDNFR- $\alpha$ and the orphan tyrosine kinase receptor Ret (Takahashi et al., 1993), thereby inducing its tyrosine phosphorylation (Treanor et al., 1996). Additional evidence of a GDNFR- $\alpha /$ RetGDNF complex was provided by Jing and collaborators (1996), who demonstrated that Ret is activated by treatment with a combination of GDNF and soluble GDNFR- $\alpha$ in cells lacking GDNFR- $\alpha$. However, other studies have suggested that GDNF exerts its biological activity solely by binding to, and phosphorylating, Ret (Durbec et al., 1996; Trupp et al., 1996). These investigators used a motor neuron cell line (Trupp et al., 1996) or Xenopus embryo assay (Durbec et al., 1996) to demonstrate their hypothesis. It is possible that this discrepancy between different reports could be attributable to a different mechanism of action of GDNF in different biological systems. It is not unlikely that Ret functions in a more widespread context than GDNF signaling, because the adult substantia nigra has been found to express high levels of $c$-ret at a time when GDNF is minimally expressed in this region (Arenas et al., 1995). Perhaps this could explain the lack of effects in the dopaminergic nigra neurons in GDNF $-/-$ animals in the present study, because cognate ligands for Ret other than GDNF might compensate for the loss of this neurotrophic factor.

In conclusion, the present data demonstrate selective effects of GDNF gene manipulation on the early development of both central and peripheral noradrenergic neurons. Future studies are needed to determine whether these changes continue during further development and whether other neuronal systems, such as the nigral dopaminergic neurons, become altered by a continued lack of this neurotrophic factor in later developmental stages or during adult life.

\section{REFERENCES}

Arenas E, Persson H (1994) Neurotrophin-3 prevents the death of adult central noradrenergic neurons in vivo. Nature 367:368-371.

Arenas E, Trupp M, Akerud P, Ibanez CF (1995) GDNF prevents degeneration and promotes the phenotype of brain noradrenergic neurons in vivo. Neuron 15:1465-1473.

Beck KD, Valverde J, Alexi T, Poulsen K, Moffat B, Vandlen RA, Rosenthal A, Hefti F (1995) Mesencephalic dopaminergic neurons protected by GDNF from axotomy-induced degeneration in the adult brain. Nature 373:339-341.

Bowenkamp KE, Hoffman AF, Gerhardt GA, Henry MA, Biddle PT, Hoffer BJ, Granholm ACH (1995) Glial cell line-derived neurotrophic factor supports survival of injured midbrain dopaminergic neurons. J Comp Neurol 355:479-489.

Buj-Bello A, Buchman VL, Horton A, Rosenthal A, Davies AM (1995) GDNF is an age-specific survival factor for sensory and autonomic neurons. Neuron 15:821-828.

Choi-Lundberg DL, Bohn MC (1995) Ontogeny and distribution of glial cell line-derived neurotrophic factor (GDNF) mRNA in the rat. Brain Res Dev Brain Res 85:80-88.

Crowley C, Spencer SD, Nishimura MC, Chen KS, Pitts-Meek S, Armanini MP, Ling LH, MacMahon SB, Shelton DL, Levinson AD (1994) Mice lacking nerve growth factor display perinatal loss of sensory and sympathetic neurons yet develop basal forebrain cholinergic neurons. Cell 76:1001-1011.

Durbec P, Marcos-Gutierrez CV, Kilkenny C, Grigoriou M, Wartiowaara K, Suvanto P, Smith D, Ponder B, Costantini F, Saarma M, Sariola H, Pachnis V (1996) GDNF-signalling through the Ret receptor tyrosine kinase. Nature 381:789-793.

Ebendal T, Tomac A, Hoffer BJ, Olson L (1995) Glial cell line-derived neurotrophic factor stimulates fiber formation and survival in cultured neurons from peripheral autonomic ganglia. J Neurosci Res 40:276-284.

Ernfors P, Ibanez CF, Ebendal T, Olson L, Persson H (1990) Molecular cloning and neurotrophic activities of a protein with structural similarities to $\beta$-nerve growth factor: developmental and topographical expression in the brain. Proc Natl Acad Sci USA 87:5454-5458.

Ernfors P, Lee K-F, Kucera J, Jaenisch RZ (1994) Lack of neurotrophin-3 leads to deficiencies in the peripheral nervous system and loss of limb proprioceptive afferents. Cell 77:503-512.

Farinas I, Jonas KR, Bachus C, Wang XY, Reichardt LF (1994) Severe sensory and sympathetic deficits in mice lacking neurotrophin-3. Nature 369:658-661.

Friedman WJ, Ibanez CF, Hallbook F, Persson H, Cain LD, Dreyfus CF, Black IB (1993) Differential actions of neurotrophins in the locus coeruleus and basal forebrain. Exp Neurol 119:72-78.

Gash DM, Zhang Z, Ovadia A, Cass WA, Yi A, Simmerman L, Russell D, Martin D, Lapchak PA, Collins F, Hoffer BJ, Gerhardt GA (1996) Functional recovery in parkinsonian monkeys treated with GDNF. Nature 380:252-255.

Gnahn H, Hefti F, Heumann R, Schwab ME, Thoenen H (1983) NGFmediated increase of cholineacetyltransferase (ChAT) in the neonatal rat forebrain: evidence for a physiological role of NGF in the brain? Brain Res 285:45-52.

Granholm A-Ch, Bäckman C, Bloom F, Ebendal T, Gerhardt GA, Hoffer BJ, Mackerlova L, Olson L, Söderström S, Walus LR, Friden PM (1994) NGF and anti-transferrin receptor antibody conjugate: short and long term effects on survival of cholinergic neurons in intraocular septal transplants. J Pharm Exp Ther 268:448-459.

Henderson CE, Phillips HS, Pollock RA, Davies AM, Lemeulle C, Armanini MN, Simmons L, Moffat B, Vandlen RA, Simpson LC, Moffet B, Vandlen RA, Koliatsos VE, Rosenthal A (1994) GDNF: a potent 
survival factor for motoneurons present in peripheral nerve and muscle. Science 266:1062-1064.

Hoffer BJ, Hoffman AF, Bowenkamp KE, Huettl P, Hudson J, Martin D, Lin L-F, Gerhardt GA (1994) Glial cell-line derived neurotrophic factor reverses toxin-induced injury to midbrain dopaminergic neurons in vivo. Neurosci Lett 182:107-111.

Honegger P, Lenoir D (1982) Nerve growth factor (NGF) stimulation of cholinergic telencephalon neurons in aggregating cell cultures. Brain Res 255:229-238.

Hudson JL, Granholm A-Ch, Gerhardt GA, Henry MA, Hoffman AF, Biddle P, Leela NS, Mackerlova L, Lile JD, Collins F, Hoffer BJ (1995) Glial cell line-derived neurotrophic factor augments midbrain dopaminergic circuits in vivo. Brain Res Bull 36:425-432.

Jing S, Wen D, Yu Y, Holst PL, Luo Y, Fang M, Tamir R, Antonio L, Hu Z, Cupples R, Louis J-C, Hu S, Altrock BW, Fox GM (1996) GDNFinduced activation of the Ret protein tyrosine kinase is mediated by GDNFR- $\alpha$, a novel receptor for GDNF. Cell 85:1113-1124.

Kearns CM, Gash DM (1995) GDNF protects nigral dopamine neurons against 6-hydroxydopamine in vivo. Brain Res 672:104-111.

Li L, Wu W, Lin LF, Lei M (1995) Rescue of adult mouse motoneurons from injury-induced cell death by glial cell line-derived neurotrophic factor. Proc Natl Acad Sci USA 92:9771-9775.

Lin LF, Doherty DH, Lile JD, Bektesh S, Collins F (1993) GDNF: a glial cell line-derived neurotrophic factor for midbrain dopaminergic neurons. Science 260:1130-1132.

Lindner MD, Winn SR, Baetge EE, Hammang JP, Gentile FT, Doherty E, McDermot PE, Frydel B, Ullman MD, Schallert T (1995) Implantation of encapsulated catecholamine and GDNF-producing cells in rats with unilateral dopamine depletions and parkinsonian symptoms. Exp Neurol 132:62-76.

Moore MW, Klein RD, Farinas I, Sauer H, Armanini M, Phillips H, Reichardt LF, Ryans AM, Carver-Moore K, Rosenthal A (1996) Renal and neuronal abnormalities in mice lacking GDNF. Nature 382:76-79.

Mount HT, Dean DO, Alberch J, Dreyfus CF, Black IB (1995) Glial cell line-derived neurotrophic factor promotes the survival and morphologic differentiation of Purkinje cells. Proc Natl Acad Sci USA 92:9092-9096.

Oppenheim RW, Houenou LJ, Johnson JE, Lin LF, Li L, Lo AC, Newsome AL, Prevette DM, Wang S (1995) Developing motor neurons rescued from programmed and axotomy-induced cell death by GDNF. Nature 373:344-346.

Pichel JG, Shen L, Sheng HZ, Granholm A-Ch, Drago J, Grinberg A, Lee EJ, Huang SP, Saarma M, Hoffer BJ, Sariolas H, Westphal H (1996) Defects in enteric innervation and kidney development in mice lacking GDNF. Nature 382:73-76.

Price ML, Hoffer BJ, Granholm A-Ch (1996) Effects of GDNF on fetal septal forebrain transplants in oculo. Exp Neurol 141:181-189.

Sanchez MP, Silos-Santiago I, Frisen J, He B, Lira SA, Barbacid M (1996) Renal agenesis and the absence of enteric neurons in mice lacking GDNF. Nature 382:70-73.
Sauer H, Rosenblad C, Björklund A (1995) Glial cell line-derived neurotrophic factor but not transforming growth factor beta 3 prevents delayed degeneration of nigral dopaminergic neurons following striatal 6-hydroxydopamine lesion. Proc Natl Acad Sci USA 92:8935-8939.

Schaar DG, Sieber B-A, Dreyfus CJ, Black IB (1993) Regional and cell-specific expression of GDNF in rat brain. Exp Neurol 124:368-371.

Springer JE, Mu X, Bergmann LW, Trojanowski JQ (1994) Expression of GDNF in rat and human nervous tissues. Exp Neurol 127:167-170.

Springer JE, Seeburger JL, He J, Gabrea A, Blankenhorn EP, Bergman LW (1995) cDNA sequence and differential mRNA upregulation of two forms of glial cell line-derived neurotrophic factor in Schwann cells and rat skeletal muscle. Exp Neurol 131:47-52.

Strömberg I, Björklund L, Johansson M, Tomac A, Collins F, Olson L, Hoffer BJ, Humpel C (1993) Glial cell-line derived neurotrophic factor is expressed in the developing but not adult striatum and stimulates developing dopamine neurons in vivo. Exp Neurol 124:401-412.

Takahashi M, Asai N, Iwashita T, Isomura T, Miyazaki K, Matsuyama M (1993) Characterization of the ret proto-oncogene products expressed in mouse L cells. Oncogene 8:2925-2929.

Tomac A, Lindqvist E, Lin L-F, Ögren S, Young D, Hoffer BJ, Olson L (1995) Protection and repair of the nigrostriatal dopaminergic system by GDNF in vivo. Nature 373:335-339.

Treanor JJS, Goodman L, de Sauvage F, Stone DM, Poulsen KT, Beck CD, Gray C, Armanini MP, Pollock RA, Hefti F, Phillips HS, Goddard A, Moore MW, Buj-Bello A, Davies AM, Asai N, Takahashi M, Vandlen R, Henderson CE, Rosenthal A (1996) Characterization of a multicomponent receptor for GDNF. Nature 382:80-83.

Trok K, Hoffer BJ, Olson L (1996) Glial cell line-derived neurotrophic factor enhances survival and growth of pre- and postnatal spinal cord transplants. Neuroscience 71:231-241.

Trupp M, Ryden M, Jornvall H, Funakoshi H, Timmusk T, Arenas E, Ibanez CF (1995) Peripheral expression and biological activities of GDNF, a new neurotrophic factor for avian and mammalian peripheral neurons. J Cell Biol 130:137-148.

Trupp M, Arenas E, Fainzilber M, Nilsson A-S, Sieber B-A, Grigoriou M, Kilkenny C, Salazar-Grueso E, Pachnis V, Arumae U, Sariola H, Saarma M, Ibanez CF (1996) Functional receptor for GDNF encoded by the c-ret proto-oncogene. Nature 381:785-789.

Williams LR, Inouye G, Cummins V, Pelleymounter MA (1996) Glial cell line-derived neurotrophic factor sustains axotomized basal forebrain cholinergic neurons in vivo: dose-response comparison to nerve growth factor and brain-derived neurotrophic factor. J Pharm Exp Ther 277:1140-1151.

Yan Q, Matheson C, Lopez OT (1995) In vivo neurotrophic effects of GDNF on neonatal and adult facial motor neurons. Nature 373:341-344.

Zurn AD, Baetge EE, Hammang JP, Tan SA, Aebisher P (1994) Glial cell line-derived neurotrophic factor (GDNF), a new neurotrophic factor for motoneurones. NeuroReport 6:113-118. 